\title{
Pengaruh Pemberian Vermikompos Terhadap Perubahan Beberapa Sifat Kimia Ultisol
}

\author{
(The Effect of Giving Vermicompost on the Changes of Chemical \\ Characteristic of Ultisol)
}

\author{
Uci Fitria ${ }^{1}$, Zuraida ${ }^{1}$, Ilyas $^{1 *}$ \\ ${ }^{1}$ Program Studi Ilmu Tanah, Fakultas Pertanian, Universitas Syiah Kuala
}

\begin{abstract}
Abstrak. Usaha pertanian di Ultisol akan menghadapi sejumlah permasalahan karena Ultisol umumnya mempunyai $\mathrm{pH}$ rendah yang menyebabkan kandungan $\mathrm{Al}$, Fe, dan $\mathrm{Mn}$ terlarut tinggi sehingga dapat meracuni tanaman. Pemupukan dengan pupuk organik dapat mengatasi kendala untuk meningkatkan produktivitas tanah ultisol, salah satunya berupa vermikompos. Vermikompos adalah pupuk organik yang diperoleh melalui proses yang melibatkan cacing tanah dalam proses penguraian atau dekomposisi bahan organiknya. Penelitian ini bertujuan untuk mempelajari pengaruh pemberian vermikompos terhadap perbaikan sifat kimia tanah Ultisol. Penelitian ini dilaksanakan di Laboratorium Kimia Tanah Fakultas Pertanian Universitas Syiah Kuala, Laboratorium Penelitian Tanah Tanaman dan Balai Pengkajian Teknologi Pertanian. Penelitian berlangsung pada Maret sampai Oktober 2017. Penelitian ini dilakukan dengan menggunakan metode Rancangan Percobaan (Experimental Design) dengan Rancangan Acak Lengkap (RAL) non faktorial. Faktor perlakuan adalah dosis vermikompos yaitu: $\mathrm{V} 0=0$ ton $/ \mathrm{ha}^{-1}, \mathrm{~V} 1=15$ ton $/ \mathrm{ha}^{-1}, \mathrm{~V} 2=20$ ton $/ \mathrm{ha}^{-1}, \mathrm{~V} 3=25$ ton $/ \mathrm{ha}^{-1}$ dan V4 = 30 ton $/ \mathrm{ha}^{-}$ 1 . Masing-masing perlakuan diulang sebanyak 4 kali. Parameter yang diamati adalah $\mathrm{pH}\left(\mathrm{H}_{2} \mathrm{O}\right.$ dan $\left.\mathrm{KCl}\right), \mathrm{C}$ Organik, $\mathrm{N}$ total, $\mathrm{P}$ tersedia, Al-dd, dan $\mathrm{C} / \mathrm{N}$. Hasil penelitian menunjukkan bahwa vermikompos dapat mempengaruhi beberapa sifat kimia tanah Ultisol Jantho. Pemberian vermikompos pada tanah Ultisol nyata meningkatkan P tersedia pada 3 dan 5 MSI, dan nyata meningkatkan C-Organik tanah pada 3 MSI. Pemberian vermikompos pada tanah Ultisol tidak memberikan pengaruh nyata terhadap $\mathrm{pH}, \mathrm{Al}-\mathrm{dd}, \mathrm{N}$ total, dan $\mathrm{C} / \mathrm{N}$.
\end{abstract}

Kata Kunci: Vermikompos, Sifat Kimia Tanah, Ultisol

\begin{abstract}
Farming in Ultisol will face a number of problems because Ultisols generally have low pH which causes high $\mathrm{Al}, \mathrm{Fe}$ and $\mathrm{Mn}$ content that can poison the plants. Fertilization with organic fertilizer can overcome the obstacles to increase ultisol productivity, one of them is vermicompost. Vermicompost is an organic fertilizer that obtained through a process involving earthworms in the process of or decomposition of organic matter.The aim of this research is to study about the effect of vermicompost toward improving the chemical characteristic of Ultisol. This research was conducted at Soil Chemistry Laboratory of Agricultural Faculty of Syiah Kuala University, Land Research Laboratory and Agricultural Technology Assessment Institute. The research took place from March to October 2017.This research is done by using Experimental Design method with non factorial Random Design (RAL). The treatment factor was vermicompost dose: V0=0 ton $/ \mathrm{ha}^{-1}, \mathrm{~V} 1=15$ ton $/ \mathrm{ha}^{-1}$, $\mathrm{V} 2=20$ ton $/ \mathrm{ha}^{-1}, \mathrm{~V} 3=25 \mathrm{ton} / \mathrm{ha}^{-1}$ and $\mathrm{V} 4=30 \mathrm{ton} / \mathrm{ha}^{-1}$. Each treatment was repeated 4 times. The parameters observed were $\mathrm{pH}\left(\mathrm{H}_{2} \mathrm{O}\right.$ and $\left.\mathrm{KCl}\right), \mathrm{C}$-Organic, $\mathrm{N}$ total, $\mathrm{P}$ available, $\mathrm{Al}-\mathrm{dd}$, and $\mathrm{C} / \mathrm{N}$. The results showed that. Using vermicompost on Ultisol soil increase $\mathrm{P}$ available at 3 and $5 \mathrm{MSI}$, and significantly improve on C-Organic soil at 3 MSI. Using vermicompost on Ultisol soil did not have significant effect on $\mathrm{pH}, \mathrm{Al}-\mathrm{dd}, \mathrm{N}$ total, and $\mathrm{C} / \mathrm{N}$.
\end{abstract}

Keywords: Vermicompost, the chemical characteristic of Ultisol

\section{PENDAHULUAN}

Ultisol, umumnya berkembang dari bahan induk tua. Ultisol merupakan bagian terluas dari lahan kering di Indonesia yang belum dipergunakan untuk pertanian, yang tersebar di daerah sumatra, Kalimantan, Sulawesi dan Irian jaya. Usaha pertanian di Ultisol akan menghadapi sejumlah permasalahan karena Ultisol umumnya mempunyai $\mathrm{pH}$ rendah yang menyebabkan kandungan $\mathrm{Al}, \mathrm{Fe}$, dan $\mathrm{Mn}$ terlarut tinggi sehingga dapat meracuni tanaman. Jenis tanah ini biasanya miskin unsur hara makro esensial seperti $\mathrm{N}, \mathrm{P}, \mathrm{K}, \mathrm{Ca}$, dan $\mathrm{Mg}$ dan unsur hara mikro $\mathrm{Zn}, \mathrm{Mo}, \mathrm{Cu}$, dan $\mathrm{B}$, serta bahan organik. Umumnya tanah Ultisol atau Podsolik Merah Kuning (PMK) banyak mengandung Al dapat dipertukarkan yaitu berkisar 20-70\% (Subandi, 2007). 
Pemupukan dengan pupuk organik dapat mengatasi kendala pemanfaatan Ultisol (Prasetyo dan Suriadikarta, 2006). Oleh karena itu, untuk meningkatkan produktivitas tanah Ultisol perlu dilakukan penambahan bahan organik salah satunya berupa vermikompos. Vermikompos adalah pupuk organik yang diperoleh melalui proses yang melibatkan cacing tanah dalam proses penguraian atau dekomposisi bahan organiknya. Menurut Handayunik (2008) penambahan bahan organik seperti vermikompos ke dalam tanah sangat penting guna menyediakan lingkungan tumbuh yang optimal bagi tanaman, pelestarian lingkungan dan menjaga kesuburan tanah.

Dengan demikian, vermikompos perlu diberikan pada tanah untuk menambahkan kesuburan tanah dan mengeliminir masalah pada tanah Ultisol. Oleh karena itu penelitian tentang penggunaan vermikompos pada tanah Ultisol perlu dilakukan.

\section{METODE PENELITIAN}

Penelitian ini dilakukan di Laboratorium Kimia Tanah Fakultas Pertanian Universitas Syiah Kuala. Analisis sifat kimia tanah dilakukan di Laboratorium Penelitian Tanah dan Tanaman (LPTT) dan di Balai Pengkajian Teknologi Pertanian (BPTP). Penelitian ini dilaksanakan pada Maret sampai Oktober 2017.

\section{MATERI DAN METODE}

Alat-alat yang digunakan pada penelitian ini adalah pot (volume $1500 \mathrm{ml}$ ), ayakan tanah dengan diameter lubang $5 \mathrm{~mm}$, timbangan analitik, oven, spektrofotometer, $\mathrm{pH}$ meter dan alat-alat gelas untuk analisis di laboratorium.

Bahan-bahan yang digunakan pada penelitian ini adalah tanah ultisol yang berasal dari Desa Aweuk, Kecamatan Jantho Kabupaten Aceh Besar, vermikompos dan bahan-bahan kimia yang diperlukan untuk analisis di Laboratorium.

Rancangan yang digunakan dalam penelitian ini adalah Rancangan Acak Lengkap (RAL) non faktorial dengan 5 taraf perlakuan dosis vermikompos yaitu: $\mathrm{V} 0=0$ ton $\mathrm{ha}^{-1}, \mathrm{~V} 1=$ 15 ton ha ${ }^{-1}, \mathrm{~V} 2=20$ ton ha ${ }^{-1}, \mathrm{~V} 3=25$ ton ha ${ }^{-1}$ dan V4 $=30$ ton ha ${ }^{-1}$. Masing-masing perlakuan diulang sebanyak 4 kali, sehingga terdapat 20 satuan percobaan

\section{Pelaksanaan Penelitian \\ Persiapan Tanah}

Tanah diambil dari kedalaman 0-20 cm dengan menggunakan cangkul, setelah itu tanah dibersihkan dari akar dan kerikil kemudian dikering-anginkan. Tanah yang telah dikering-anginkan, diayak dengan pengayak tanah berdiameter lubang $5 \mathrm{~mm}$. Tanah yang telah diayak digunakan untuk penelitian sebanyak $1 \mathrm{~kg} /$ pot (kadar air 4,4 \% ).

\section{Pemberian vermikompos}

Dosis Vermikompos dihitung berdasarkan Berat Kering Mutlak (BKM) pada suhu 105 ${ }^{\circ} \mathrm{C}$, (kadar airnya 180\%). Pencampuran Vermikompos dengan tanah dilakukan sebelum tanah dimasukkan ke dalam pot sesuai dengan perlakuan masing-masing. Inkubasi tanah dilakukan dalam kondisi kapasitas lapang selama 3 dan 5 minggu.

\section{Parameter Pengamatan}


Parameter sifat kimia tanah yang diamati pada 3 dan 5 Minggu Setelah Inkubasi (MSI) adalah:

1. $\mathrm{pH} \mathrm{H}_{2} \mathrm{O}$ dan $\mathrm{pH} \mathrm{KCl}$

2. C- Organik

3. $\mathrm{N}$ total

4. $\mathrm{P}$ tersedia

5. Al-dd

6. $\mathrm{C} / \mathrm{N}$

\section{HASIL DAN PEMBAHASAN}

\section{Sifat Kimia Tanah Awal dan Vermikompos}

Berdasarkan identifikasi tanah di lapangan, jenis tanah di lokasi penelitian adalah Ultisol. Hasil analisis awal tanah penelitian disajikan pada Tabel 1.

Tabel 1. Hasil Analisis awal sifat kimia tanah Ultisol Jantho, Aceh Besar.

\begin{tabular}{llcc}
\hline \multicolumn{2}{l}{ Sifat Kimia tanah } & Hasil & Kriteria \\
\hline $\mathrm{pH} \mathrm{H} \mathrm{H}_{2} \mathrm{O}$ & 5,38 & Masam \\
pH KCl & & 3,87 & Sangat masam \\
C-Organik $(\%)$ & 0,66 & Sangat rendah \\
$\mathrm{N}$ total & $(\%)$ & 0,24 & Sedang \\
$\mathrm{P}$ tersedia & $(\mathrm{ppm})$ & 2,85 & Sangat rendah \\
$\mathrm{Ca}$ & $(\mathrm{cmol} \mathrm{kg}-1)$ & 6,73 & Sedang \\
$\mathrm{Mg}$ & $\left(\mathrm{cmol} \mathrm{kg}^{-1}\right)$ & 0,38 & Rendah \\
$\mathrm{K}$ & $\left(\mathrm{cmol} \mathrm{kg}^{-1}\right)$ & 0,13 & Tinggi \\
$\mathrm{Na}$ & $\left(\mathrm{cmol} \mathrm{kg}^{-1}\right)$ & 0,22 & Tinggi \\
$\mathrm{KTK}$ & $\left(\mathrm{cmol} \mathrm{kg}^{-1}\right)$ & 15,60 & Rendah \\
$\mathrm{KB}$ & $(\%)$ & 47,82 & Sedang \\
$\mathrm{Al}-\mathrm{dd}$ & $(\mathrm{cmol} \mathrm{kg}$ & 1,00 & Rendah \\
$\mathrm{DHL}$ & $\left(\mathrm{mS} \mathrm{cm}^{-1}\right)$ & 0,05 & Sangat rendah \\
$\mathrm{C} / \mathrm{N}$ & & 8,25 & Rendah \\
\hline
\end{tabular}

Berdasarkan data pada Tabel 1, tanah ini memiliki tingkat kesuburan yang rendah, yang ditujukan dari nilai $\mathrm{pH}$ yang masam, kandungan $\mathrm{C}$-Organik dan $\mathrm{P}$ tersedia sangat rendah. Menurut Hardjowigeno (1993) pemberian bahan organik pada tanah Ultisol, dapat memperbaiki kesuburan tanah karena pemberian bahan organik akan menurunkan kemasaman tanah.

Hasil analisis vermikompos disajikan pada Tabel 2. Menurut Novizan (2001) kompos yang baik adalah yang memiliki $\mathrm{C} / \mathrm{N}$ rasio $12-15 \%$. Bahan vermikompos yang digunakan memiliki nilai $\mathrm{C} / \mathrm{N} 13,38 \%$, dengan demikian vermikompos ini sudah tergolong baik untuk digunakan sebagai pupuk organik, karena sudah sesuai dengan kualitas standar pupuk organik.

Tabel 2. Hasil Analisis sifat kimia Vermikompos. 


\begin{tabular}{ll}
\hline \multicolumn{2}{l}{ Sifat Kimia Vermikompos } \\
\hline $\mathrm{pH}$ & 7,35 \\
$\mathrm{C}-$ Organik $(\%)$ & 14,32 \\
$\mathrm{~N}$ total $\quad(\%)$ & 1,07 \\
$\mathrm{P}$ total $\quad(\%)$ & 1,77 \\
$\mathrm{C} / \mathrm{N}$ & 13,38 \\
\hline
\end{tabular}

Berdasarkan Tabel 2, hasil analisis vermikompos di laboratorium memiliki $\mathrm{pH}=7,35$, C-Organik $=14,32 \%, \mathrm{P}$ Total $=1,77 \%, \mathrm{~N}$ total $=1,07 \%$, dan $\mathrm{C} / \mathrm{N}=13,38 \%$. Lisa (2013) menyatakan suatu bahan yang mengandung unsur $\mathrm{C}$ tinggi maka nilai $\mathrm{C} / \mathrm{N}$ rasionya juga akan tinggi, sebaliknya bahan yang mengandung unsur $\mathrm{C}$ rendah maka nilai $\mathrm{C} / \mathrm{N}$ rasionya rendah.

\section{Sifat Kimia Tanah Setelah Pemberian Vermikompos Kemasaman Tanah (pH Tanah)}

Hasil analisis ragam menunjukkan bahwa perlakuan dosis vermikompos berpengaruh tidak nyata terhadap kadar $\mathrm{pH} \mathrm{H}_{2} \mathrm{O}$ dan $\mathrm{pH} \mathrm{KCl}$.

Tabel 3. Rata-rata $\mathrm{pH} \mathrm{H}_{2} \mathrm{O}$ dan $\mathrm{KCl}$ setelah Pemberian Vermikompos pada 3 dan 5 MSI.

\begin{tabular}{|c|c|c|c|c|}
\hline \multirow{2}{*}{$\begin{array}{c}\text { Dosis } \\
\text { Vermikompos } \\
\left(\text { ton } / \mathrm{ha}^{-1}\right)\end{array}$} & \multicolumn{2}{|c|}{$\mathrm{pH}\left(\mathrm{H}_{2} \mathrm{O}\right)$} & \multicolumn{2}{|c|}{$\mathrm{pH}(\mathrm{KCl})$} \\
\hline & 3 MSI & $5 \mathrm{MSI}$ & $3 \mathrm{MSI}$ & $5 \mathrm{MSI}$ \\
\hline 0 & 6,3 & 6,3 & 5,4 & 5,2 \\
\hline 15 & 6,3 & 6,3 & 5,2 & 5,2 \\
\hline 20 & 6,4 & 6,3 & 5,1 & 5,3 \\
\hline 25 & 6,3 & 6,4 & 5,3 & 5,5 \\
\hline 30 & 6,2 & 6,4 & 5,2 & 5,5 \\
\hline Rata-rata & 6,29 & 6,35 & 5,25 & 5,35 \\
\hline
\end{tabular}

Analisis awal $\mathrm{pH} \quad \mathrm{H}_{2} \mathrm{O}$ tanah adalah 5,38 (kriteria masam), setelah diberikan vermikompos pada $3 \mathrm{MSI}, \mathrm{pH} \mathrm{H}_{2} \mathrm{O}$ tanah meningkat dengan nilai tertinggi dijumpai pada dosis 20 ton $/ \mathrm{ha}^{-1}$ yaitu 6,4 (kriteria agak masam). Analisis awal $\mathrm{pH} \mathrm{KCl}$ tanah adalah 3,87 (sangat masam), setelah diberikan perlakuan vermikompos dan inkubasi pada $3 \mathrm{MSI}$, nilai $\mathrm{pH}$ $\mathrm{KCl}$ meningkat menjadi 5,3 pada dosis 25 ton $\mathrm{ha}^{-1}$ (kriteria agak masam). Penambahan masa inkubasi hingga 5 MSI meningkatkan $\mathrm{pH} \mathrm{KCl}$ tanah menjadi 5,5.

Perlakuan dosis vermikompos pada tanah penelitian tidak menaikkan nilai $\mathrm{pH} \mathrm{H}_{2} \mathrm{O}$ dan $\mathrm{pH} \mathrm{KCl}$ yang signifikan secara statistik. Kadar Al-dd yang rendah pada tanah penelitian merupakan salah satu hal yang menunjukkan perbedaan dosis tidak nyata terhadap perubahan pH tanah (Tabel 3). Diduga penyebab sumber kemasaman tanah penelitian disebabkan adanya Fe yang lebih dominan didasarkan dari hasil penelitian Duana (2018), yang menyatakan bahwa tanah di lahan penelitian memiliki bentuk fraksi Fe-P (462,62 ppm) yang lebih dominan dibandingkan bentuk $\mathrm{Al}$ - $\mathrm{P}(10,66 \mathrm{ppm})$.

Rata-rata hasil analisis $\mathrm{pH} \mathrm{H}_{2} \mathrm{O}$ dan $\mathrm{pH} \mathrm{KCl}$ tanah sebelum dan sesudah perlakuan vermikompos pada tanah Ultisol Jantho disajikan pada Gambar 1. Gambar 1 menunjukkan sesudah pemberian vermikompos pada masa 3 dan $5 \mathrm{MSI}$, dapat meningkatkan $\mathrm{pH}_{2} \mathrm{O}, \mathrm{pH}$ $\mathrm{KCl}$ tanah. Pemberian vermikompos dapat meningkatkan $\mathrm{pH}$ tanah awal, diduga 
vermikompos dapat menetralisir sumber kemasaman tanah sehingga dapat menurunkan potensial kemasaman tanah.

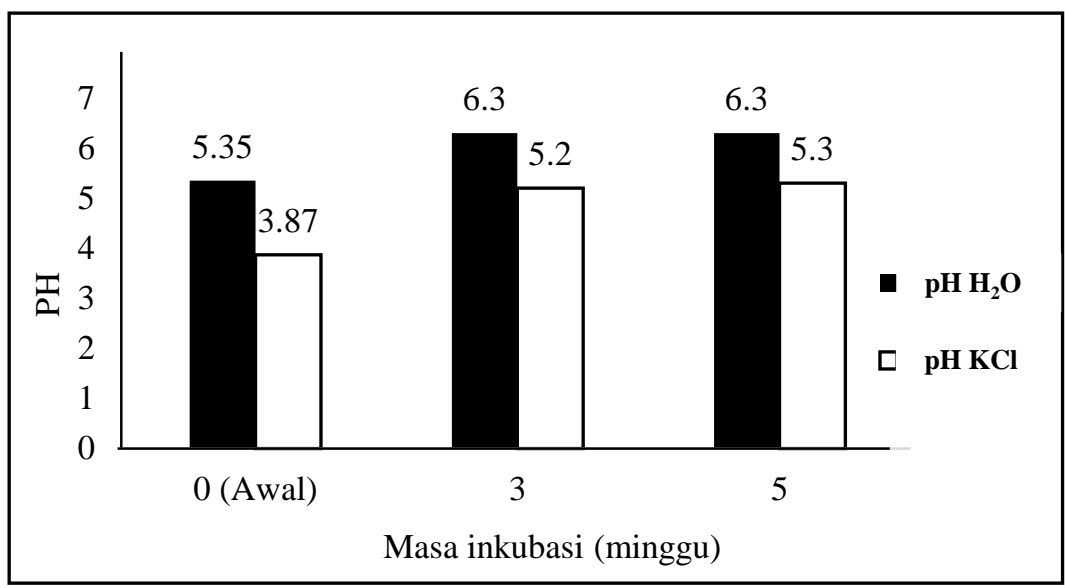

Gambar 1. Rata-rata $\mathrm{pH} \mathrm{H}_{2} \mathrm{O}$ dan $\mathrm{pH} \mathrm{KCl} \mathrm{Tanah} \mathrm{Ultisol} \mathrm{Jantho} \mathrm{Sebelum} \mathrm{dan}$ Sesudah Perlakuan Vermikompos.

\section{C-Organik}

Hasil analisis ragam menunjukkan bahwa perlakuan dosis vermikompos berpengaruh nyata pada 3 MSI terhadap kadar C-Organik tanah.

Tabel 4. Rata-rata C-Organik Setelah Pemberian Vermikompos pada 3 dan 5 MSI.

\begin{tabular}{ccc}
\hline Dosis & \multicolumn{1}{c}{ C-Organik (\%) } \\
\cline { 2 - 3 } $\begin{array}{c}\text { Vermikompos } \\
\text { (ton/ha) }\end{array}$ & $3 \mathrm{MSI}$ & $5 \mathrm{MSI}$ \\
\hline 0 & $1,56 \mathrm{a}$ & $1,52 \mathrm{a}$ \\
15 & $1,67 \mathrm{a}$ & $1,52 \mathrm{a}$ \\
20 & $1,64 \mathrm{a}$ & $1,60 \mathrm{a}$ \\
25 & $1,60 \mathrm{a}$ & $1,67 \mathrm{a}$ \\
30 & $1,76 \mathrm{~b}$ & $1,59 \mathrm{a}$ \\
\hline BNT $_{0.05}$ & 0,12 & 0,21 \\
\hline
\end{tabular}

Ket: Angka yang diikuti oleh huruf yang sama pada kolom yang sama tidak berbeda nyata.

Analisis awal C-Organik tanah yaitu 0,66\% (kriteria sangat rendah). Setelah diberikan perlakuan vermikompos pada 3 MSI terjadi peningkatan kadar C-Organik tanah namun masih pada (kriteria rendah).

Penggunaan dosis vermikompos dapat meningkatkan kadar C-Organik tanah karena vermikompos mengandung C-Organik yang tinggi yaitu 14,32 \% sehingga dapat menambah kadar C-Organik ke dalam tanah. Hal ini sejalan dengan penelitian Khairani et al (2010), nilai C-Organik pada vermikompos tinggi $11 \%$. Hasil analisis C-Organik tanah sebelum dan sesudah perlakuan vermikompos pada tanah Ultisol Jantho disajikan pada Gambar 2. 


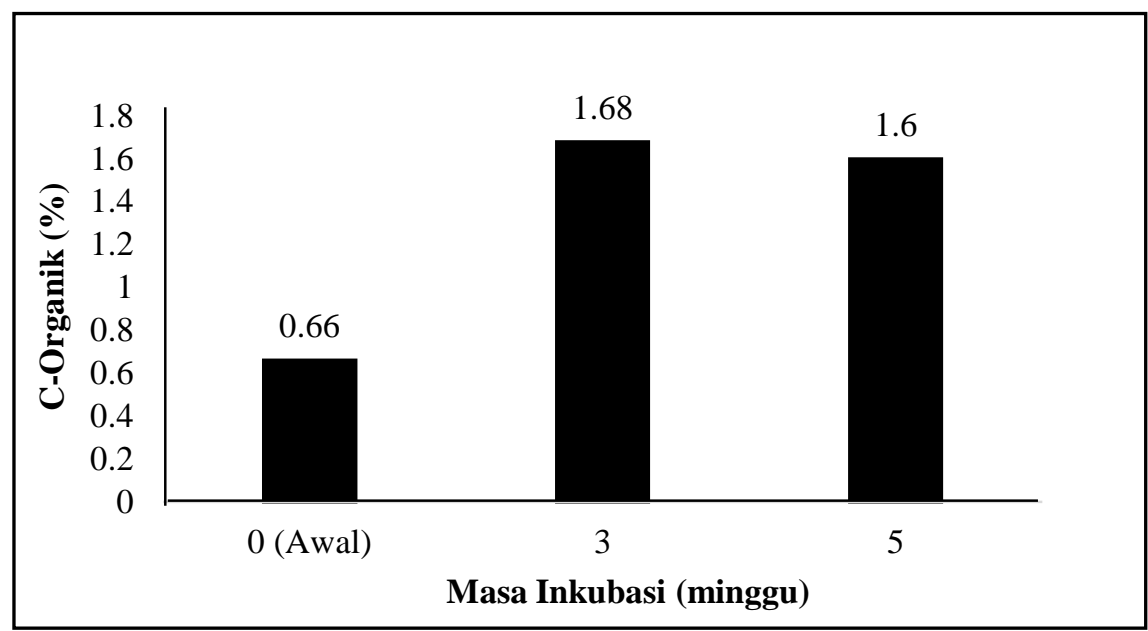

Gambar 2. Rata-rata C-Organik Tanah Ultisol Jantho Sebelum dan Sesudah Perlakuan Vermikompos.

Berdasarkan Gambar 2, pemberian vermikompos pada masa 3 dan 5 MSI, dapat meningkatkan C-Organik tanah. Kadar C-Organik pada masa inkubasi 3 MSI diperoleh lebih tinggi dari kadar C-Organik pada 5 MSI, disebabkan pada minggu ke 5 kadar C-Organik banyak hilang digunakan sebagai sumber energi mikroorganisme, respirasi mikroba tanah dan sebagian lagi dilepaskan menjadi gas $\mathrm{CO}_{2}$. Mirwan (2015) menyatakan bahwa C-Organik merupakan karbon yang digunakan sebagai sumber energi mikroorganisme untuk menyusun sel-sel dengan membebaskan $\mathrm{CO}_{2}$ dan bahan lainnya.

\section{$\mathbf{N}$ total}

Hasil analisis ragam menunjukkan bahwa perlakuan dosis vermikompos berpengaruh tidak nyata terhadap $\mathrm{N}$ total.

Tabel 5. Rata-rata $\mathrm{N}$ total tanah setelah Pemberian Vermikompos pada 3 dan 5 MSI.

\begin{tabular}{ccc}
\hline Dosis & \multicolumn{2}{c}{$\mathrm{N}$ total (\%) } \\
\cline { 2 - 3 } Vermikompos (ton/ha) & 3 MSI & MSI \\
\hline 0 & 0,12 & 0,11 \\
15 & 0,14 & 0,11 \\
20 & 0,14 & 0,12 \\
25 & 0,10 & 0,13 \\
30 & 0,14 & 0,14 \\
\hline Rata-rata & 0,13 & 0,12
\end{tabular}

Analisis awal $\mathrm{N}$ total tanah yaitu $0,24 \%$ (kriteria sedang). Setelah diberikan perlakuan vermikompos pada 3 MSI terjadi penurunan kadar $\mathrm{N}$ total tanah (kriteria rendah). Penambahan masa inkubasi menjadi 5 MSI juga menurunkan kadar $\mathrm{N}$ total tanah (kriteria rendah).

Perlakuan dosis vermikompos tidak memberikan pengaruh yang nyata, karena vermikompos yang diberikan pada tanah memiliki kandungan $\mathrm{N}$ yang rendah, kondisi ini sesuai dengan pernyataan Sofyan et al (2009) bahwa kadar $\mathrm{N}$ total dari setiap jenis 
vermikompos berbeda-beda, kadar $\mathrm{N}$ tertinggi dimiliki oleh Amynthas gracilis sebesar 0,40\% dan terendah dimiliki oleh Pheretima sebesar $0,17 \%$. Hasil analisis N-total tanah sebelum dan sesudah perlakuan vermikompos pada tanah Ultisol Jantho disajikan pada Gambar 3.

Rendahnya kandungan $\mathrm{N}$-total tanah akibat pemberian vermikompos ini diduga karena dikonsumsikan oleh mikroorganisme sehingga hara N berkurang. Hardjowigeno (2003) menjelaskan bahwa proses hilangnya $\mathrm{N}$ yang ada di dalam tanah dapat disebabkan karena diserap oleh tanaman, digunakan oleh mikroorganisme, dan mudah tercuci.

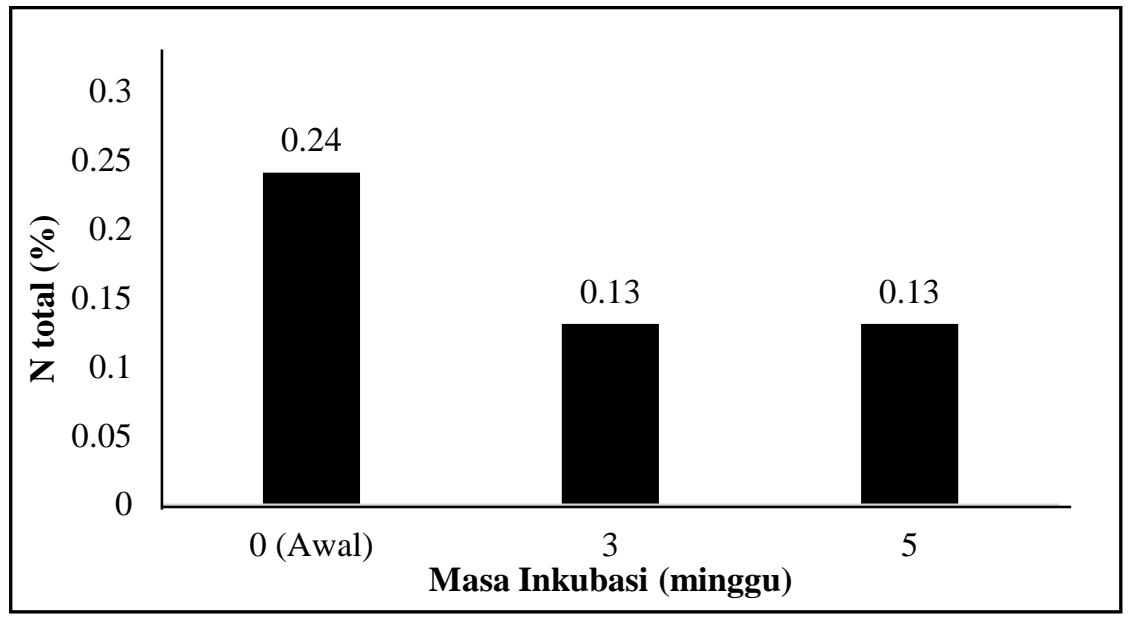

Gambar 3. Rata-rata N-total Tanah Ultisol Jantho Sebelum dan Sesudah Perlakuan Vermikompos.

\section{P-tersedia}

Kadar P-tersedia tanah pada analisis ragam menunjukkan pengaruh sangat nyata pada 3 dan 5 MSI setelah diberi perlakuan vermikompos.

Tabel 6. Rata-rata P tersedia setelah Pemberian Vermikompos pada 3 dan 5 MSI.

Ket: Angka yang diikuti oleh huruf yang sama pada kolom yang sama tidak berbeda nyata.

\begin{tabular}{ccc}
\hline Dosis & \multicolumn{2}{c}{ P-tersedia (ppm) } \\
\cline { 2 - 3 } Vermikompos (ton/ha) & 3 MSI & 5 MSI \\
\hline 0 & $0,67 \mathrm{a}$ & $2,16 \mathrm{a}$ \\
15 & $2,51 \mathrm{~b}$ & $3,06 \mathrm{~b}$ \\
20 & $3,08 \mathrm{c}$ & $3,16 \mathrm{~b}$ \\
25 & $3,34 \mathrm{c}$ & $4,17 \mathrm{c}$ \\
\hline 30 & $4,31 \mathrm{~d}$ & 0,64 \\
\hline
\end{tabular}

Perlakuan dosis vermikompos memberikan pengaruh sangat nyata pada perubahan kadar P-tersedia tanah setelah 3 MSI, dengan rata- rata tertinggi dijumpai pada dosis 30 ton $\mathrm{ha}^{-1}$ sebesar 4,31 ppm (kriteria sangat rendah) yang berbeda sangat nyata dengan perlakuan lainnya. Penambahan masa inkubasi hingga 5 minggu, menurunkan P-tersedia tanah pada dosis vermikompos 20, 25, dan 30 ton ha $^{-1}$ masing- masing sebesar 3,06 ppm, 3,16 ppm, dan 4,17 ppm.

Pemberian vermikompos pada tanah mampu menurunkan $\mathrm{P}$ yang teradsorpsi dalam tanah. Vermikompos akan menghasilkan asam-asam organik yang memegang peranan 
penting dalam pengikatan $\mathrm{Al}$ dan $\mathrm{Fe}$, sehingga $\mathrm{P}$ menjadi tersedia. Hasil analisis $\mathrm{P}$ tersedia tanah sebelum dan sesudah perlakuan vermikompos pada tanah Ultisol Jantho disajikan pada Gambar 4.

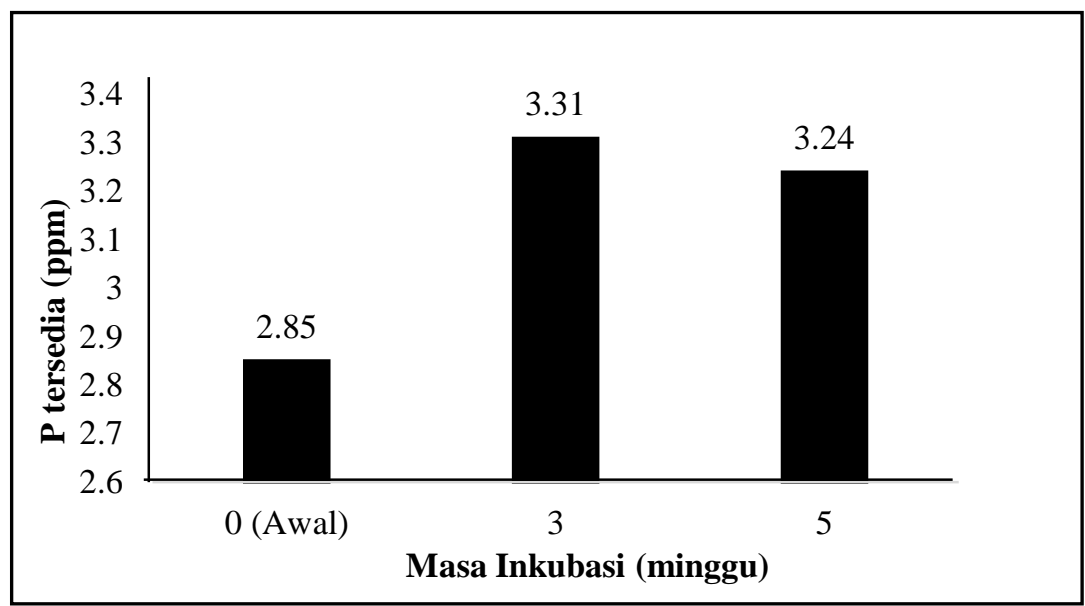

Gambar 4. Rata-rata P tersedia Tanah Ultisol Jantho Sebelum dan Sesudah Perlakuan Vermikompos.

Berdasarkan Gambar 4 pemberian vermikompos pada masa 3 dan 5 MSI, dapat meningkatkan $\mathrm{P}$ tersedia tanah. Kandungan $\mathrm{P}$ dalam vermikompos tinggi dan aplikasi vermikompos mampu menurunkan $\mathrm{P}$ yang teradsorpsi dalam tanah. Keadaan ini sesuai dengan pendapat Rusnetty (2000) yang mengemukakan bahwa penambahan bahan organik akan memberikan pengaruh positif terhadap kelarutan fosfat di dalam tanah.

Gampar 6 menunjukkan hubungan antara dosis vermikompos dengan P-tersedia tanah pada 3 dan 5 MSI. Peningkatan dosis vermikompos pada 3 MSI meningkatkan $\mathrm{P}$ tersedia tanah secara linear $(Y=0,69+0,116 X)$ dengan nilai koefisien korelasi $r^{2}=0,99$, demikian juga terjadi peningkatan $\mathrm{P}$ tersedia tanah pada 5 MSI dengan persamaan regresi linear $(\mathrm{Y}=$ $1,13+0,094 X), r^{2}=0,97$.

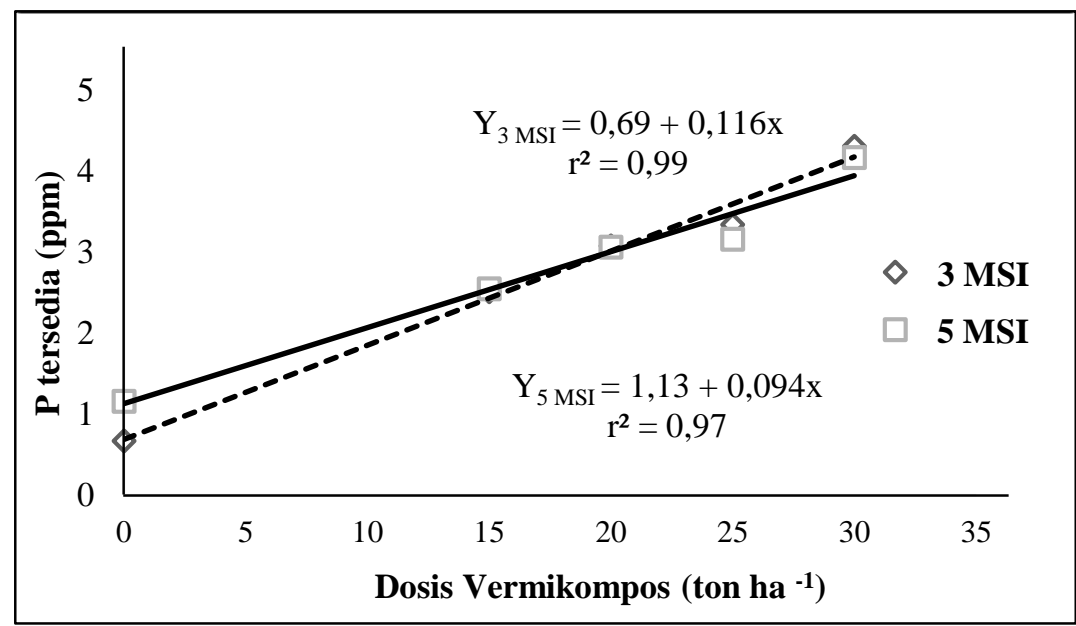

Gambar 5. Hubungan Antara Dosis Vermikompos dengan P-tersedia Tanah pada 3 dan 5 MSI. 
Berdasarkan persamaan tersebut diketahui P-tersedia tanah pada 3 MSI tanpa pemberian vermikompos memiliki $=0,69 \mathrm{ppm}$. Pemberian setiap ton dosis vermikompos dapat mempengaruhi peningkatan P-tersedia tanah sebesar 0,116 ppm. Pemberian vermikompos mempengaruhi perubahan P-tersedia tanah penelitian sebesar 99\%, sedangkan pengaruh lainnya terhadap perubahan $\mathrm{P}$-tersedia adalah $0,1 \%$.

Pada 5 MSI, Tanah tanpa pemberian vermikompos memiliki rata-rata P-tersedia tanah $=1,13$ ppm. Pemberian dosis vermikompos setiap ton meningkatkan P-tersedia tanah sebesar 0,094 ppm. Perlakuan dosis vermikompos terhadap perubahan P-tersedia tanah penelitian berpengaruh sebesar 97\%. Sedangkan pengaruh lainnya adalah 0,3\%. Penambahan dosis 20 ton ha ${ }^{-1}$ pada masa inkubasi 3 dan 5 MSI, terjadi kenaikan kadar P tersedia yang tetap yaitu $3,01 \mathrm{ppm}$.

\section{Al-dd}

Hasil analisis ragam menunjukkan bahwa perlakuan dosis vermikompos berpengaruh tidak nyata terhadap kadar Al-dd.

Tabel 7. Rata-rata Al-dd setelah Pemberian Vermikompos pada 3 dan 5 MSI

\begin{tabular}{ccc}
\hline Dosis & \multicolumn{2}{c}{ Al-dd $\left(\mathrm{cmol} \mathrm{kg}^{-1}\right)$} \\
\cline { 2 - 3 } Vermikompos $\left(\right.$ ton $\left./ \mathrm{ha}^{-1}\right)$ & 3 MSI & MSI \\
\hline 0 & 0,70 & 0,70 \\
15 & 0,40 & 0,70 \\
20 & 0,80 & 0,80 \\
25 & 0,70 & 0,60 \\
30 & 0,70 & 0,90 \\
\hline Rata-rata & 0,68 & 0,72
\end{tabular}

Analisis awal Al-dd tanah adalah 1,00 $\mathrm{cmol} \mathrm{kg}^{-1}$ (kriteria rendah), setelah diberikan perlakuan vermikompos pada 3 dan 5 MSI, terjadi penurunan kadar Al-dd tanah. Penurunan Al-dd pada perlakuan vermikompos, disebabkan karena senyawa organik hasil dekomposisi vermikompos mengikat Al sehingga kadar Al-dd tanah menurun. Dengan penurunan Al-dd maka akan meningkatkan $\mathrm{pH}$ tanah dan P-tersedia tanah (Tabel 3 dan 6). Hal ini disebabkan $\mathrm{Al}^{3+}$ merupakan logam yang dapat mengikat $\mathrm{P}$ dan membuat $\mathrm{pH}$ menjadi masam.

Perhitungan dari beberapa studi menunjukkan bahwa pada $\mathrm{pH}<5,0 \mathrm{Al}$ menduduki $50 \%$ dari jumlah kation - kation dapat ditukar, sedangkan pada $\mathrm{pH}$ 5,6 kation - kation basa menduduki 94\% dari jumlah kation dapat ditukar (Sabiham et al.,1978). Berdasarkan hal tersebut, maka pertukaran aktif dalam suatu tanah yang mempunyai $\mathrm{pH}<5,0$ komplek jerapan diduduki Al. Hasil analisis Al-dd tanah sebelum dan sesudah perlakuan vermikompos pada tanah Ultisol Jantho disajikan pada Gambar 6. 


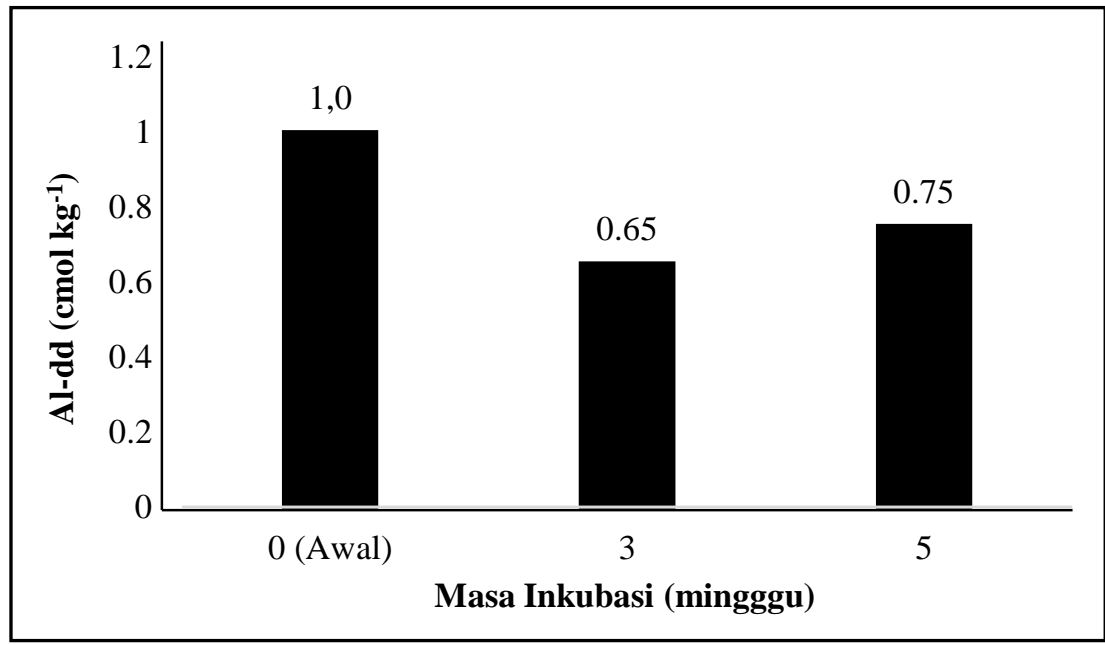

Gambar 6. Rata rata Al-dd Tanah Ultisol Jantho Sebelum dan Sesudah Perlakuan Vermikompos.

\section{$\mathbf{C} / \mathbf{N}$}

Hasil analisis ragam menunjukkan bahwa perlakuan dosis vermikompos berpengaruh tidak nyata terhadap $\mathrm{C} / \mathrm{N}$.

Tabel 8. Rata-rata $\mathrm{C} / \mathrm{N}$ tanah setelah pemberian vermikompos pada 3 dan 5 MSI

\begin{tabular}{ccc}
\hline Dosis & & C/N \\
\cline { 2 - 3 } Vermikompos (ton/ha) & 3 MSI & 5 MSI \\
\hline 0 & 12,88 & 13,90 \\
15 & 12,41 & 14,07 \\
20 & 11,96 & 13,16 \\
25 & 13,78 & 14,17 \\
30 & 13,10 & 11,65 \\
\hline Rata-rata & 12,82 & 13,39 \\
\hline
\end{tabular}

Perlakuan dosis vermikompos tidak memberikan pengaruh yang nyata terhadap $\mathrm{C} / \mathrm{N}$ tanah pada 3 MSI dan 5 MSI. Pada tanah awal diperoleh nilai C/N 8,25 (rendah) sedangkan nilai $\mathrm{C} / \mathrm{N}$ vermikompos diperoleh 13,38 . Nilai $\mathrm{C} / \mathrm{N}$ dalam tanah dikelompokkan dalam lima kategori yaitu: sangat rendah untuk nilai $\mathrm{C} / \mathrm{N}$ berkisar $(<5)$, rendah untuk $\mathrm{C} / \mathrm{N}$ berkisar $(5-$ 10), sedang untuk $\mathrm{C} / \mathrm{N}$ berkisar (11-15), tinggi untuk $\mathrm{C} / \mathrm{N}$ berkisar (16-25) dan sangat tinggi untuk $\mathrm{C} / \mathrm{N}(>25)$. Nilai $\mathrm{C}: \mathrm{N}$ rasio tanah relatif konstan pada kisaran 8:1 sampai 15:1 dengan rata-rata 10:1 sampai 12:1 (Prasad dan Power, 1997).

Perlakuan vermikompos pada 3 MSI dan 5 MSI terjadi peningkatan nilai $\mathrm{C} / \mathrm{N}$ (Gambar 7), rata-rata nilai $\mathrm{C} / \mathrm{N}$ pada $3 \mathrm{MSI}$ adalah 12,81 dan rata-rata nilai $\mathrm{C} / \mathrm{N}$ pada $5 \mathrm{MSI}$ adalah 13,26. Peningkatan nilai $\mathrm{C} / \mathrm{N}$ diduga karena pengaruh pemberian vermikompos pada tanah yang dapat menambah kandungan $\mathrm{C}$ dalam tanah, sehingga mampu meningkatkan nilai $\mathrm{C} / \mathrm{N}$ tanah yang awalnya rendah. 


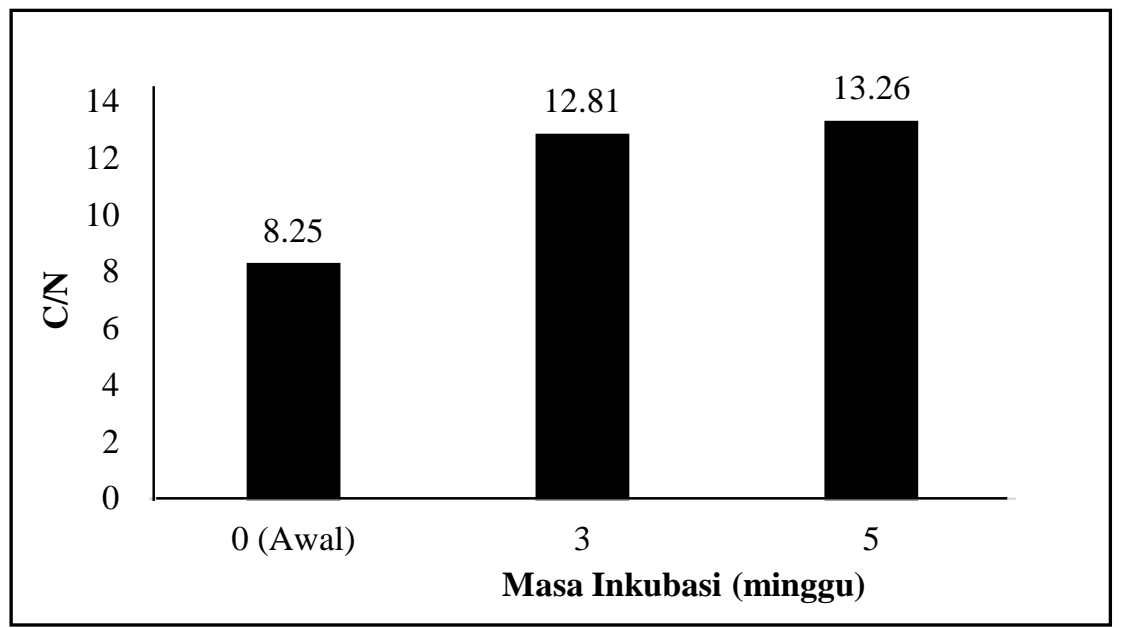

Gambar 7. Rata-rata C/N Tanah Ultisol Jantho Sebelum dan Sesudah Perlakuan Vermikompos.

\section{KESIMPULAN DAN SARAN}

Vermikompos dapat mempengaruhi beberapa sifat kimia tanah ultisol Jantho. Pemberian vermikompos pada tanah Ultisol nyata meningkatkan P tersedia pada 3 dan 5 MSI, dan nyata meningkatkan C-Organik tanah pada 3 MSI. Perlakuan dosis vermikompos pada tanah Ultisol tidak memberikan pengaruh nyata terhadap $\mathrm{pH}, \mathrm{Al}-\mathrm{dd}, \mathrm{N}$ total, dan $\mathrm{C} / \mathrm{N}$.

\section{DAFTAR PUSTAKA}

Erisa, D. 2018. Kajian Fraksionasi Fosfor (P) pada Beberapa Pola Penggunaan Lahan Kering Ultisol di Desa Jalin Jamtho Aceh Besar. Skripsi. Universitas Syiah Kuala, Banda Aceh.

Hanafiah, AS., T Sabrina. dan H Guchi. 2009. Biologi dan Ekologi Tanah. Universitas Sumatera Utara. Medan.

Handayunik, W. 2008. Pengaruh Pemberian Kompos Limbah Padat Tempe Terhadap Sifat Fisik, Kimia Tanah Serta Efisiensi Terhadap Urea Pada Entisol Wajak Malang. Skripsi. Universitas Brawijaya, Malang.

Hardjowigeno, S. 2003. Ilmu Tanah. Akademika. Presindo. Jakarta.

Hasibuan, B.E. 2006. Ilmu Tanah. USU Perss. Medan.

Hidayati, Y.A., Ellin H. dan T.M. Eulis 2008a Analisis Kandungan N, P, dan K Pada Lumpur Hasil Ikatan Gasbio (Sludge) Yang Terbuat Dari Feses Sapi Perah, Semnas Puslitbangnak-Bogor.

Khairani, I., Hartati S., dan Mujiyo. 2010. Pengaruh Kascing Dan Pupuk Anorganik Terhadap Ketersediaan Nitrogen Pada Alfisols Jumantono Dan Serapannya Oleh Tanaman Jagung Manis (Zea Mays L. Saccharata). Skripsi. Universitas Sebelas Maret, Surakarta.

Lisa, P. 2013. Pengaruh Berbagai Aktivator Terhadap Aktivitas Dekomposer Dan Kwalitas Kompos Blotong Dari Limbah Pabrik Gula. Fakutas pertanian. Universitas Muhammadiyah Yogyakarta. Yogyakarta.

Mashur, 2001. Teknologi Vermikomposting. Instalasi Penelitian dan Pengkajian Teknologi Pertanian. Mataram. 
Mirwan, M. 2015. Optimasi Pengomposan Sampah Kebun Dengan Variasi Aerasi dan Penambahan Kotoran Sapi Sebagai Bioaktivator. Jurnal Ilmiah Teknik Lingkungan 4(1):61-66.

Novizan. 2001. Petunjuk Pemupukan yang efektif. Agromedia Pustaka. Tanggerang.

Prasad, R. and J. F. Power. 1997. Soil Fertility Management for Suistanable Agriculture. Lewis Pulb, New York.

Prasetyo, B.H. dan D. A. Suriadikarta. 2006. Karakteristik, Potensi, dan Teknologi Pengelolaan Tanah Ultisol Untuk Pengembangan Pertanian Lahan Kering Di Indonesia. Balai Besar Penelitian dan Pengembangan Sumberdaya Lahan Pertanian. Jurnal Litbang Pertanian. 25 (2). 9 hlm.

Rusnetty. 2000. Beberapa Sifat Kimia Serapan P, Fraksional AI dan Fe Tanah, Serapan Hara, Serta Hasil Jagung Akibat Pemberian Bahan Organik dan Fosfat Alam Pada Utisols Sitiung. Disertasi. Unpad. Bandung.

Sabiham, S., T. B. Prasetyo dan S. Dohong. 1978. Phonelic Acid In Indonesia Peat In J.O. Riely and S.E. Page (eds). Pp. 289-292., Biodiversity and Sustamability Environmental Inportance and Sustainability of Tropical Pdeat and Peatlands, held in Palangka Raya.

Sofyan AE., Damayanti., Julendra. 2009. Aktivitas antibakteri dan retensi protein tepung cacing tanah (Lumbricus rubellus) sebagai pakan imbuhan dengan taraf penambahan kitosan. JITV. Hal 182-187.

Subandi, 2007. Teknologi Produksi dan Strategi Pengembangn Kedelai pada Lahan Kering Masam. Iptek Tanaman Pangan. Vol 2, No.1. 